This is the peer reviewed version of the following article:

Bloch, H. 2016. Prices in Motion: Towards a Schumpeterian Price Theory.

Metroeconomica: International review of economics. 67 (4): pp. 742-767, which has been published in final form at http://doi.org/10.1111/meca.12119 .

This article may be used for non-commercial purposes in accordance with Wiley Terms and Conditions for Self-Archiving at http://olabout.wiley.com/WileyCDA/Section/id-828039.html 


\title{
Prices in Motion: Towards a Schumpeterian Price Theory*
}

\author{
Harry Bloch \\ School of Economics and Finance \\ Curtin University \\ GPO Box U 1987 \\ Perth WA 6845 \\ h.bloch@curtin.edu.au
}

\begin{abstract}
To Schumpeter, endogenous development is an essential characteristic of capitalism that disrupts the equilibrium of the circular flow of the economy. Price equilibrium in the circular flow is displaced by an analysis of prices in motion. The diversion of productive inputs from their existing employment through competition from entrepreneurs and the process of creative destruction both impact on prices throughout the economy and generate business cycles. While Schumpeter's theory of the business cycle and, implicitly, his price theory, have been heavily criticized, this paper suggests a way forward to a revised theory of prices in motion.
\end{abstract}

Key words: Schumpeter, Price theory, Evolutionary economics

JEL codes: B5, D4, E3

*Helpful comments on an earlier version of this paper were received from participants at the 2013 conference of the History of Economic Thought Society of Australia. Jerry Courvisanos and Stan Metcalfe have separately provided helpful suggestions, as have two anonymous referees of this journal. The author takes full responsibility for any remaining errors or omissions. 


\section{Introduction}

Schumpeter makes a fundamental contribution to economic theory by distinguishing between the process of economic development and the general equilibrium that characterizes the circular flow in a static economy.

'Development in our sense is a distinct phenomenon, entirely foreign to what may be observed in the circular flow or in the tendency to equilibrium. It is spontaneous and discontinuous change in the channels of the flow, disturbance of equilibrium, which forever alters and displaces the equilibrium state previously existing.' (Schumpeter 1961 [1934]: 64)

To Schumpeter, endogenous development is an essential characteristic of capitalism and, thus, incorporating the disruptive process of innovation associated with development is crucial to the proper analysis of capitalist economies.

By focussing on innovation, Schumpeter introduces an element of dynamics into price theory. Price equilibrium in the circular flow is displaced by an analysis of prices in motion. In particular, the entrepreneur who introduces the innovation receives a price that exceeds cost, but profit is transitory as this profit attracts imitators.

Expansion of production by the entrepreneur and its imitators initially push up prices of inputs to production, while the prices charged by the entrepreneur's competitors are pushed down once the extra production from the innovator comes on the market. These ups and downs in prices leave the structure of prices in the economy permanently changed, corresponding to the structural change that innovation brings to production and consumption. In addition, Schumpeter's argues that the net 
effect of the ups and downs in individual prices is a rise in the price level in the early years after a wave of innovations, followed by a larger decrease in later years. Thus, innovations impart cyclical movements in the aggregate price level around a long-run downward trend as well as changing the system of relative prices to reflect the differential impact of innovation.

In contrast to the general interest in Schumpeter's work on economic development, little attention has been given to his contribution to price theory. In part, this reflects the highly critical reviews given to Business Cycles (Schumpeter 1939), which contains his most extensive discussion of price theory. A particular point of controversy has been Schumpeter's argument that the business cycle begins and ends in the neighbourhood of equilibrium of the Walrasian type. The prices associated with this equilibrium are taken to define the "normal" prices for the economy. The contradiction between discontinuities of innovation and a model of equilibrium creates inherent difficulties that are noted in various critiques.

Schumpeter's great insight nevertheless remains valid, namely that understanding capitalist development requires an analysis of implications of innovation for the evolutionary process of the economy, including prices in motion. This involves examining how prices move relative to costs over the business cycle and a corresponding examination of how costs evolve both over the cycle and between cycles. Particularly in his later writings, Schumpeter acknowledges the evolution of market structure, particularly the increasing role for large established firms in both the innovation process and the ongoing processes of production and distribution. This institutional change alters price determination relative to that of a perfectly competitive economy. 
In addition to the, at least temporary, suspension of perfect competition noted by Schumpeter, I argue below that the pricing analysis needs to account for the threat of obsolescence through creative destruction in a developing economy. Actual losses to obsolescence don't directly enter into pricing as they are unknown until too late. However, the prospect of such losses can be expected to generally affect pricing behaviour, particularly by entrepreneurial firms with market power.

Market power and the threat of obsolescence lead to prices in a developing economy that can be expected to exceed reproduction costs in terms of prime and intermediate inputs actually used up in the production process. In this sense, prices are higher than they would be in a stationary economy with the same technology. Of course, technological developments tend to reduce costs or improve product quality over time. Thus, as Schumpeter argues, it is wrong to conclude that the developing economy at rest is in any way inferior to the stationary economy. Indeed, the fundamental difference between a stationary economy and a developing economy means that they each require a fundamentally distinct price (and welfare) theory.

A revised theory of prices in motion is developed in this article, starting from Schumpeter's seminal contribution of pro-cyclical entrepreneurial profit with the reconstructed elements that address criticisms of his original theory. At the micro level, a dominant price leader sets price by applying a mark-up factor, reflecting their market power and the threat of obsolescence, to unit direct cost, which is determined by productivity and current input prices. The meso-level process is then analysed as a process in which average profit margins rise and then fall as established producers are replaced by innovators. Finally, at the macro level, the derived aggregate price level is the product of four components: an index of prices of primary inputs (labour and raw materials), an average entrepreneurial profit margin weighted by the market share of 
innovators, the average mark-up factor applied by the price leaders, and an average value of productivity.

The next section contains a concise exposition of Schumpeter's theory of both the price level and the price system. Criticisms of his theory and the implications for the theory of prices in motion are developed in Section 3. Section 4 then presents a revised theory that incorporates both original and reconstructed elements of Schumpeter's theory, while Section 5 concludes.

\section{Schumpeter's price theory}

Entrepreneurial profit, which results when innovation causes a divergence between product price and cost, characterizes all of Schumpeter's examples of innovation (new processes, new products, new markets, new sources of supply of raw materials and new forms of organization) in The Theory of Economic Development (Schumpeter, 1961 [1934]). Importantly, while the profits for an individual entrepreneur are transitory, entrepreneurial profit for the system continues as long as there is economic development. The central role of such profits in the process of economic development differentiates his theoretical structure from mainstream theory. ${ }^{1}$

The differentiation between development and the circular flow is elaborated into a theory of price in Business Cycles (Schumpeter, 1939). Here, Schumpeter addresses the impact of innovations on the price level and the price system, as well as providing detailed discussion of the movement of prices of particular commodities. Most importantly from the perspective of understanding the nature of his price theory

\footnotetext{
${ }^{1}$ Mainstream price theory associates innovation with imperfect competition and monopoly profits, creating a superficial similarity to Schumpeter's theory. However, monopoly profits are consistent with equilibrium in both the short and long run, whereas Schumpeter's theory incorporates entrepreneurial profit only under the conditions of discontinuous change. Importantly, profit tends to disappear from the system in Schumpeter's theory at both the beginning and the end of the business cycle, such that "normal" prices in his system don't include economic profit.
} 
as it applies to economic development, he argues that there is a pattern of interrelated movements in prices of particular commodities, the price system and the price level that reflects the evolution of the capitalist economy.

a. The theoretical framework

The analysis in Business Cycles expands the treatment of the time dimension in Schumpeter's analysis from the rudiments given in The Theory of Economic Development. In particular, Schumpeter argues for a particular pattern of swarms of innovations and extensively analyses the working out of the adjustment to these swarms over time. Schumpeter proceeds by a series of approximations. In the first approximation, the cycle has two phases: prosperity and recession.

Prosperity occurs when entrepreneurs establish their new enterprises competing for resources already employed elsewhere in the economy by established firms. The prosperity continues during the rapid expansion of the entrepreneurial firms, enhanced by imitation of the new products and production processes by new entrants and at least some established firms. However, this expansion has limits.

As the volume of output by the entrepreneurial firm and its imitators continues to expand, the market for these products becomes saturated and prices fall, marking the onset of the recession phase of the cycle. This recession phase is a period of consolidation rather than decline. Output continues to rise as a result of the prior expansion of capacity by entrepreneurial firms and their imitators. It is only profit and price that fall in the manner normally associated with recession (see Schumpeter 1939, pp. 142-3).

Schumpeter's second approximation adds depression and recovery to the twophase cycle to create a four-phase cycle. The extra phases are a response to excessive 
expansion following an innovation and are associated with what Schumpeter labels the secondary wave. While Schumpeter argues that depression and recovery are not necessary to economic development, each of the long cycles examined by Schumpeter in Business Cycles is found to have depression and recovery phases in addition to prosperity and recession phases.

The third approximation discussed by Schumpeter considers the existence of overlapping cycles of different durations. Schumpeter identifies three cycle lengths that he finds useful in applying his theory to the historical record; Kitchin cycles lasting a little over three years, Juglar cycles lasting for approximately 9 and a half years and Kondratieff cycles lasting for approximately 57 years. ${ }^{2}$ He notes that the timing and amplitude of each of the cycles is subject to variation and that cycles are often disrupted by external factors. The idea that repetition of disruption leads to wave-like motion is fundamental, while the regularity of the timing pattern is not.

\section{b. The price level}

Schumpeter's specific discussion of prices in Business Cycles begins at the macro level in Chapter VIII, The Price Level. Here, he first emphasizes the holistic nature of his approach, warning that, 'The fact that price-level series are first to be discussed should not be interpreted to mean that we consider them first in either causal or symptomatic importance.' (Schumpeter 1939, p. 449) However, he goes on to note, 'Our analysis, however, leads us to believe that at least the symptomatic value of price movements should be great.' (Schumpeter 1939, p. 450) This apparent contradiction reflects the difficulties that Schumpeter faces in applying his holistic analysis of

\footnotetext{
${ }^{2}$ Schumpeter is careful to note that, 'it cannot be emphasized too strongly that the three-cycle schema does not follow directly from our model - although multiplicity of cycles does - and that approval of it or objection to it does not add to or detract from the value or otherwise of our fundamental idea' (Schumpeter, 1939, pp. 169-170)
} 
patterns of change in the process of economic development to individual measures, recognising the discontinuous and uneven nature of economic development and the multitude of other factors that impinge on each measure.

Although his analysis is holistic, price movements provide a logical starting point for Schumpeter's discussion of movements in measures of economic activity. By focusing on the price level Schumpeter is able to provide clearer predictions than are possible for individual prices or for many other economic aggregates. In particular, he states:

'Expectations from the pure model are so definite as to make it superfluous to elaborate them beyond what has been said in Chap. IV. Price level should rise in prosperity - under the pressure of credit creation, which, under conditions embodied in the pure model, would not be compensated either by an increase in output or by any fall in "velocity" - and fall in the downgrade - under the pressure of autodeflation and of increase in output - more than it had risen in the preceding prosperity.' (Schumpeter 1939, p. 462, italics in original)

In allowing for the second approximation in his theory, Schumpeter notes, 'But the most important difference made by the second approximation - the substitution for the two-phase of a four-phase cycle - adds the expectation that the price level will go on falling in depression and that this fall should be corrected in recovery.' (Schumpeter 1939, p. 462) Thus, the price level overshoots the fall required for the full absorption of innovations and is expected to deviate both above and below the downward trend associated with the innovation process over the course of a cycle. 
Schumpeter goes on to specifically address the argument that the price level is related to gold production (in an era when the major industrial countries still generally aspired to peg their currencies to gold). Essentially, Schumpeter argues that the supply of monetary gold is endogenous and subservient to the working of the capitalist process that he is analysing. Schumpeter holds a similar position with respect to the supply of fiat currency in discussing those historical periods where countries have moved away from the gold standard. ${ }^{3}$

c. The price system - prices of individual commodities

Innovation, as the driving force of economic development, impacts on the structure of economic activity in Schumpeter's theory. This implies that there are necessarily changes in relative prices, or in what Schumpeter refers to as the price system. While some aspects of changes in the price system are discussed in Chapter VIII, most of the discussion is postponed to Chapter X, Prices and Quantities of Individual Commodities. Here, Schumpeter deals with the details of the diverse character of price movements across commodities and with their relation to corresponding movements in quantities.

Following on from innovation, the price system changes so that the prices of products where there has been successful innovation fall, in at least quality-adjusted terms, relative to prices of products not undergoing innovation. ${ }^{4}$ This change does not occur instantaneously or uniformly according to Schumpeter. As a result, 'The reader should therefore realize from the outset ... that expectation from our model is not for uniformity but for what we actually find, great variety of amplitudes, periods, and

\footnotetext{
${ }^{3}$ See, for example, his discussion of the movements of the American price level during the long wave of 1787 to 1842, an era of free banking (Schumpeter 1939, pp. 292-296).

${ }^{4}$ A potential exception is when the innovation involves the reorganization of the producers in the market to form a cartel or in some other way to increase market power and raise prices above the cost of production without any improvement in product quality.
} 
sequences that does not tell in the least against an all-pervading movement and does not spell theoretical, although it does spell statistical, irregularity.' (Schumpeter 1939, pp. 521-2)

This disclaimer is followed by description of price movements for a range of commodities, each deflated by an aggregate price level measure, which generally show distinct cyclical behaviour, albeit with differing amplitudes, periods and sequences. Schumpeter notes that, 'The moral of the story is that only analysis of the history of the state of an industry will explain the behavior of its price-quantity pairs.' (Schumpeter 1939, p. 525) Further complications to potential price-quantity patterns are noted in Schumpeter's discussion of special cases in which there are lags in production, such as coffee, hogs and shipbuilding.

\section{Criticisms and Reconstruction}

Early criticism of Business Cycles occurs in a negative review in the American Economic Review by Kuznets (1940). Kuznets focuses primarily on the empirical content, but he also expresses serious doubts about the theoretical foundation for the clustering of innovations and the regularity of business cycles. As Freeman (1990) notes, the timing of publication was not favourable, coming on the eve of World War II and with Keynesianism well as established as the flavour of the day. Not surprisingly, Business Cycles languished in relative neglect for many decades. Freeman notes that library borrowings and citations only picked up with the general resurgence of interest in Schumpeter's work from the 1980s onward, particularly with increased interest in long waves of economic growth.

Appearing fifty years after Kuznets (1940), Freeman's (1990) reappraisal of Business Cycles is sympathetic to Schumpeter's insight that innovation is associated 
with disruption of the normal pattern of economic life. However, he is critical of Schumpeter's 'preoccupation with the individual entrepreneur and the individual innovation, and his failure to conceptualize invention, innovation and technology accumulation as a social process.' (Freeman 1990, p. 24) Freeman closes by reviewing some then recent developments in the analysis of long waves of economic development and suggests, 'they do indicate a real possibility of overcoming some of the weaknesses in Schumpeter's pioneering formulation.' (Freeman 1990, p.32)

On the historical record, Schumpeter's prediction of a downward result trend for the price level over the long cycle is clearly invalidated by the experience of the Kondratieff cycle covering the second half of the $20^{\text {th }}$ Century and his schema of smooth cycles around the long-cycle trend is difficult to support (even allowing for disturbing influences). Yet, there is clear support from the data for his argument that capitalist development is unstable and that prices are subject to substantial fluctuations with upswings and downswings lasting a number of years. Also, there are many researchers who see merit in associating this instability, at least in part, with the impact of innovations and resulting bouts of creative destruction.

This section seeks to identify aspects of Schumpeter's theory that are flawed, preliminary to development of a neo-Schumpeterian price theory. Schumpeter's treatment of monetary and financial institutions and the empirical data on movements in the price level are discussed in Section 3.a, leading to the conclusion that the evolution of institutions needs to be incorporated into a revised price theory. In Section 3.b, it is argued that theoretical normal prices for a developing economy exceed the costs of reproduction by a margin that includes the influence of market power and an allowance for the threat obsolescence faced by irreversible investments with embodied technology. 
a. Money, credit and the price level

Schumpeter can be faulted for not following his own insights while addressing the dynamics of the price level in Business Cycles. Specifically, he doesn't allow adequately for the evolution of the institutions of capitalism, particularly monetary and financial institutions. Modern commercial banks bear little resemblance to the family-run businesses of Victorian England, while the intermittent use of the gold standard has been displaced by the actions of independent central banks and the International Monetary Fund. Also, the economic role of governments, both domestically and through international organizations, has been revolutionized. These institutions, including those affecting wage-bargaining arrangements in labour markets and regulation of competition in product markets, influence the price level through altering the dynamics of the wage-price spiral as well as impacting on credit conditions and monetary expansion.

With particular regard to the role of the money and banking system, Warburton (1953, p.521) argues that the Schumpeterian system should be altered to recognize that business depressions, 'are the consequences of external factors associated with the banking and monetary system - or, more specifically, originate in shocks of monetary disequilibrium (failure to maintain the quantity of the circulating medium or events or actions expected or designed to contract the circulating medium).' This is no minor amendment, as the endogeneity of the money supply is central to Schumpeter's analysis. Bank creation of money and credit features prominently in explaining the ability of new entrepreneurial firms to initiate an upswing and an accommodating, but not excessive, money supply is central to his conclusion that the result trend for the price level is downward over the full cycle. 
The bulk of Schumpeter's (1939) detailed data on prices are for the period from some time into the 1800s through to the 1930s. These data cover at least one full Kondratieff cycle in Schumpeter's scheme, the Kondratieff from 1842 to 1897 . They also cover part of the following Kondratieff, including the initial upswing, the recession and the depression. Longer times series, such as those presented by Fischer (1996, p. 4) covering English prices of consumables for the period from 1201 to 1993, show a pattern of price level movements for the $19^{\text {th }}$ and early $20^{\text {th }}$ Century that more or less fits the pattern of Schumpeter's cyclical and trend movements. However, the pattern is not repeated over other periods.

Fischer notes that prices in England were stable to declining throughout the $19^{\text {th }}$ century, aside from an upswing around mid century. Fischer characterizes this period as the Victorian equilibrium. He also notes two other long periods in which long-run inflation was absent, the Renaissance equilibrium (1400 - 1480) and the Enlightenment equilibrium (1660 - 1730). Before, after and in between were long periods of sustained inflation, to which Fischer puts the label, price revolutions.

This characterization of alternating periods of long-term price equilibrium and price revolution is not consistent with Schumpeter's expected pattern of cycle and trend. Fischer (1996, p.9) specifically states, 'It should be understood clearly that movements we are studying are waves - not cycles. To repeat: not cycles, but waves.' The distinction to Fischer (ibid) is between cycles that 'are fixed and regular' and waves that 'differ in duration, magnitude, velocity, and momentum.' Fischer's data on price level movements from the $13^{\text {th }}$ Century onwards also provide clear evidence against Schumpeter's theory that the price level has a downward result trend. There are too many price revolutions exhibiting sustained inflation, including the revolution 
of the $20^{\text {th }}$ Century. Thus, Schumpeter's theory fails the predictive power test with regard to trend movements in the aggregate price level.

Systemic changes in the world monetary system have undermined Schumpeter's theory that money and credit expand and contract in response solely to the ebb and flow of innovations. For the modern period, say since the early 1900s, governments and monetary authorities have taken an active role in credit creation and money supply with specific intent of influencing the price level and the dynamics of inflation. The level of liquidity available in the world economy is no longer determined solely by the profit-seeking behaviour of private banks. Central banks in the major industrial countries take an increasingly interventionist position in money markets, and creation of the International Monetary Fund in the aftermath of the Second World War has enabled coordinated control of liquidity. ${ }^{5}$

Institutions beyond those affecting money and credit play roles in determining the price level. In particular, institutions that influence the outcome of the conflict between labour and employers over wage rates have been pointed out as having substantial impact on the dynamics of the wage-price spiral (see Rowthorn, 1977 and Sarantis, 1991). Also, in recent decades the actions of the Organization of Petroleum Exporting Countries (OPEC) have been connected to spikes in the price of oil, which feed through into general price inflation. ${ }^{6}$

Developments in monetary and other government and non-government institutions have undermined the prediction of his theory for the result trend for the

\footnotetext{
${ }^{5}$ These changes had begun before the writing of Business Cycles and are recognized by Schumpeter, particularly in his discussion of the reaction to the economic crisis of the 1930s by the US Federal Reserve Bank and the Bank of England (Schumpeter, 1939, pp. 885-905). However, central bank intervention at the time was focussed on dealing with financial crises rather than guiding the long-run development of the economy.

${ }^{6}$ More generally it has been argued that the institutions of the global economy have resulted in a longrun downward trend in the price of primary commodities relative to manufactures, which has a deflationary impact on the general price level (see Prebisch, 1950; Singer, 1950).
} 
price level. Of course, the evolution of the institutions of capitalist economies would not surprise Schumpeter, as his holistic analysis encompasses institutional change as part of economic development. Institutional evolution can be incorporated into a revision of Schumpeter's price theory. Alternatively, a more limited approach is to incorporate the specific monetary, financial and government institutions of the time into the analysis of the price level for any historical period. The latter approach is less satisfactory in terms of generality but potentially more manageable and is the approach adopted in Section 4 below.

At the most basic level Schumpeter's essential contribution to the theory of the price level is his emphasis on the instability of capitalism. The historical evidence certainly supports the proposition that the price level is unstable. Where Schumpeter was over ambitious, and perhaps inconsistent with his own logic, was in trying to impose a uniform repetitive pattern on this instability. The price level is best understood in terms of an evolutionary process rather than in terms of movements away from and back to equilibrium. The challenge is to understand the forces driving this motion. Importantly, these are not exclusively, or even primarily, the equilibrating forces of neoclassical theory.

Among the forces identified by Schumpeter as propelling prices in motion is the uneven temporal pattern of innovations in the economy. Schumpeter argues for a regular cyclical pattern to these innovations, subject to external disturbances of war, drought and other non-economic events. Others, such as Mensch (1975), Tylecote (1992), Freeman and Louçã (2001) and Lipsey, et al (2005), argue instead for irregular long waves of development resulting from the bunching of innovations, generally associated with breakthrough technologies. However, none of these longwave theorists contradicts Schumpeter's expectation of a pulse in the price level from 
the bunching of innovations, with an inflationary impact during the early years followed by a deflationary impact as the innovations mature and attract imitators.

b. Creative destruction, the firm and the theoretical normal of the price system In comments particularly relevant to assessing Schumpeter's price theory, Freeman suggests that Schumpeter 'had a theory of entrepreneurship without a theory of the firm.' (Freeman 1990, p.26) Further, Freeman notes that, 'Both in Theory of Economic Development and in Business Cycles Schumpeter represents boom as a departure from equilibrium and recession as a return to equilibrium in largely Walrasian terms.' (Freeman 1990, p.27) This means that Schumpeter's price theory relies implicitly on the Walrasian theory and its assumption of static competitive general equilibrium, at least in so far as determining the theoretical normal to which prices converge at the beginning and end of the business cycle.

Oakley (1990) also questions Schumpeter's use of Walrasian equilibrium as the beginning and ending point of the cycle. In referring to the circular-flow equilibrium being re-established after a wave of innovation, Oakley notes that, 'It is readily apparent that this fiction, with its new entrepreneurs, new plants, new firms and new credit simply added into Schumpeter's perception of the circular-flow conditions, led him to grossly understate the complexity of the traverses that comprise economic development and the business cycle.' (Oakley 1990, p. 233) Yet, Oakley supports Schumpeter on the argument that the economy in motion has a centre of gravity, 'It follows that at least in some ill-defined sense, some empirical centre of gravity must exist. The extent to which it can be analytically defined and applied must remain a moot point.' (Oakley 1990, p.240) 
Andersen (2012) reinforces the aforementioned complaints about Business Cycles, noting, 'In retrospect, the shortcomings of this book can be traced back to its depiction of macroevolution as a series of circular flows.' (Andersen 2012, p. 636) Andersen points to the need for a theory of microevolutionary processes as the basis for macroevolution. He further suggests that hints about constructing such a theory can be found in Schumpeter's other works, particularly Capitalism Socialism and Democracy (Schumpeter 1950 [1942]).

Schumpeter associates successful entrepreneurship with profit, hence with price exceeding the cost of production. Cost for the entrepreneur may fall with price remaining constant, as in the case of process innovation, or price might rise with cost remaining constant, as can occur with product innovation, or there may be some combination of falling cost and rising price. ${ }^{7}$ However, in each case entrepreneurial profit is transitory and dissipates over time with expansion by the entrepreneur as well as imitation by other new or established firms.

While Schumpeter is clear that dynamic competition leads to dissipation of entrepreneurial profit, he does not fully develop the analysis of the pattern of entrepreneurial behaviour and competitive response that leads to this dissipation. As such, the conclusion that competition between entrepreneurs and established firms leads to dissipation of profit cannot be assured. Indeed, in Capitalism, Socialism and Democracy Schumpeter (1950 [1942]) seemingly retreats from the notion that monopoly and monopoly profits are completely eliminated from an economy in equilibrium.

If profits are not dissipated through dynamic competition, the argument that the system returns to the theoretical normal of Walrasian equilibrium is further

\footnotetext{
${ }^{7}$ Even rising costs may occur when the product improves to such an extent that price can be increased by more than the increase in cost, as in the case of new products that better meet the needs of the buyer.
} 
undermined. Yet, the idea that an environment with prices at some sort of normal level encourages innovation by enhancing the reliability of prediction of entrepreneurial profits is appealing. What sort of prices can play this role and yet be consistent with an ongoing process of economic development?

It is possible to accept Schumpeter's proposition the business cycle ends with entrepreneurial profit approaching zero and yet reject the proposition that this leaves in the economy in the perfectly competitive equilibrium of a stationary state. The economy at this starting point has experienced innovations and their diffusion, which should be considered the usual circumstance of the economy. Firms can reasonably expect further innovations that will have the general characteristic of increasing productivity through the process of creative destruction. ${ }^{8}$ How will the costs and prices for this developing economy differ from those of the stationary economy?

Production in the modern economy generally requires long-lasting capital equipment that embodies technology, for example, machinery with fixed requirements of primary and intermediate inputs to produce a given amount of output. Also, labour often has skills specific to the current technology of production, such as training in operating the aforementioned machinery. Changing technology lowers the future returns to these inputs when the products of the new technology compete with those of the old. In the extreme, the investments embodying the old technology have zero value and are obsolete.

Lower expected future returns to owners of the inputs used with embodied technology makes investment in embodying that technology less attractive unless compensated by an increase in expected prices received for the outputs in the early

\footnotetext{
${ }^{8}$ Improved productivity in a broad sense is a characteristic of all of Schumpeter's categories of innovation. This is most obvious in the case of process innovations that reduce cost by saving on input requirements. However, any innovation that results in profits gives more value to the buyer than the costs of its production, a situation analogous that for process innovations.
} 
years of that investment. Take the case of incremental improvements in capital equipment, such that each vintage of machines has lower labour requirements than the preceding vintage. If the price of output were just sufficient to cover the operating cost of labour and materials plus proportional depreciation of the newest vintage, all previous vintages of equipment would be operating at a loss as the product price would be below their reproduction cost based on proportional depreciation. This implies that, in the developing economy, prices for established firms with investments in embodied technology won't fall to the level of reproduction costs, even in the fullness of time. Thus, in a developing economy, the current prices of outputs from investments with embodied technology can be expected to exceed the current prices for the products from using the same technology in Schumpeter's stationary economy in equilibrium. In this way, the expected future development of the economy increases the theoretical normal for prices.

It may seem surprising that a developing economy would be characterized by a higher cost structure than a stationary economy with the same technology. However, there is an option value to uncommitted productive inputs in the developing economy that is not present in the stationary economy. The option value is lost once these inputs are committed to the current technology, either through embodiment of the technology in a machine or training of a worker. There is no loss of option value in the stationary economy because there is no expectation that technology will ever change. In this sense, it should not be inferred that the higher costs mean that the developing economy is in any way inferior to the stationary economy.

It also needs to be noted that an economy undergoing development has rising productivity, so that the normal condition of the economy is one of cost and price reduction through innovation. Comparison of prices between the developing economy 
and the stationary economy misses the importance of technical progress to the growth of well-being. Schumpeter (1942 [1950], p.106) makes this point forcefully, 'In this respect, perfect competition is not only impossible but inferior, and has no title to being set up as a model of ideal efficiency.'

An established firm in a developing economy has committed inputs across a range of activities, including production, marketing, distribution, research and internal organization of the firm. These committed inputs are all subject to loss of value in the event of future innovations. In the case of fixed plant and equipment, extreme loss in the form of obsolescence occurs when the embodied technology becomes more expensive to operate than to replace with new plant and equipment. Prior to full obsolescence there is an erosion of value, as the capital plus operating costs of production with new technology falls relative to the operating cost of the old plant and equipment. A similar process occurs with other committed inputs to the extent that they can't be adapted to new technology, such as when consumer loyalty to existing products is eroded by product innovations of competitors or when a company's business model is rendered inferior by the development of improved methods.

Accounting methods sometimes recognize the potential loss of value to production equipment from creative destruction by using depreciation charges for plant and equipment that exceed the rate of physical deterioration. The expected useful life in these cases is based on the length of time for which the plant and equipment is expected to remain profitable to operate rather than the time at which the plant and equipment wears out. Computer equipment may thus be assigned a useful life of three years rather than the five or ten years for which the physical components of the equipment may be expected to keep functioning. However, such allowances for 
potential obsolescence are the exception rather than the rule. ${ }^{9}$ The key difficulty is that the nature of future innovations is unknown so their adverse impact on current investments can't be known, nor can the probability distribution of impacts be known.

Essentially, in a developing economy the proper allocation over time of the costs of investments in embodied technology is only revealed ex post. At the time of investment, the impact of creative destruction is unknown and so the level of price required to cover these costs is also unknown. All that is reasonably certain is that, in at least some cases, production with embodied technology will cease prematurely due to competition from new technology. Accelerating the depreciation of inputs committed to embedded technology is thus reasonable ex ante, but the amount of depreciation that would recover the cost of the inputs is only known ex post.

\section{Prices in motion - the revised price system}

As Andersen (2012) notes, Schumpeter lacks a theory of the microevolutionary processes on which to rest his theory of macroevolution. Alternatively, as Oakley (1990) notes, Schumpeter understates the complexity of the traverses that comprise economic development and the business cycle. I approach filling in these gaps through consideration of firm pricing behaviour (micro-level analysis), adding interfirm dynamic competition (meso-level analysis) as a driver of cyclical movement in prices affecting the price system with implications for the price level, and then considering institutional settings to analyse the movement of the price level.

My purpose is to impose minimal restrictions in modelling firm pricing behaviour, at least initially. Following the criticisms of Schumpeter's use of

\footnotetext{
${ }^{9}$ When creative destruction reduces the value of investments in embodied technology, the value of the investments may be recognized through a revaluation of assets and associated charge against current earnings. In the extreme case, the loss of value can be so large as to lead to bankruptcy, which Schumpeter acknowledges as a possible outcome of creative destruction.
} 
Walrasian general equilibrium, I particularly avoid imposing the marginal conditions required for that equilibrium. Instead, I start with a simple accounting relation that holds whenever firms earn zero profits, following Schumpeter's assumption for the initial stationary state of the economy. Ignoring intermediate inputs and durable capital for simplicity, the price for any established (mature) firm then satisfies: ${ }^{10}$

$p_{m}=(x / y)_{m} w$,

where $p_{m}$ is an index of the price of the firm's products, $(x / y)_{m}$ is an inverse index of the firm's productivity given as an index, $x$, of its use of primary inputs (labour and raw materials) relative to an index of its outputs, $y$, and $w$ gives an index of the prices of its inputs (wages and primary commodity prices), which for simplicity is assumed to be the same for all firms. ${ }^{11}$ Allowing for durable capital and overhead expenses, but retaining the zero-profit condition yields:

$p_{m}=\mu_{m}(x / y)_{m} w, \quad \quad \mu_{m}=(1+z) \geq 1$

where $\mu_{m}$ is a measure of the firm's gross margin on unit direct cost and $z$ is the ratio of unit indirect cost (overhead and capital depreciation) to unit direct cost.

So far expressions in the general form of (1) and (2) are just accounting identities used to impose zero-profit conditions at the level of a vertically integrated firm producing finished goods. However, expressions such as these are used by postKeynesian economists as pricing rules for firms, which involve giving both the gross profit margin and unit direct cost behavioural interpretations that deviate at least to some extent from their accounting definitions.

\footnotetext{
${ }^{10}$ The exclusion of intermediate inputs implies that production is vertically integrated within the firm, at least with regard to non-primary inputs. As Steedman (1992) notes this is far from an innocuous assumption if one is interested in analysing effects on the price system. In the analysis of the price system below, I acknowledge the possibility of further complications due the interdependence of prices when some products are used as intermediate inputs.

${ }^{11}$ One type of innovation mentioned by Schumpeter is developing new (cheaper?) sources of supply of raw materials. This case is not explicitly considered here, but would not lead to fundamentally different outcomes than the case discussed below of a process innovation that increases productivity for the innovator.
} 
In the post-Keynesian pricing analysis, unit indirect costs are those associated with the normal (expected) level of output, so variations in output don't lead to price changes even though overhead cost per unit does change. Further, direct costs are generally assumed invariant to output based on an assumption of underutilized capacity and fixed technology in the short run. Thus, for short-run analysis, the inputoutput (inverted productivity) level and gross profit margin are exogenous and constant, which implies that only source of short-run variation in price is variation in the prices of labour and raw materials.

The pricing rules in (1) and (2) are consistent with Schumpeter's price theory in the sense that under "normal" conditions they can generate zero-profit outcomes for all firms, but allow for deviations when circumstances aren't normal as with the introduction of innovations. Further, the rule in (2) can be easily generalized by having the gross profit margin exceed one plus the ratio of indirect to direct cost, which would allow for market power and obsolescence under "normal" conditions as suggested in Section 3.b above. Importantly, the rules don't impose the restrictions of optimization or market clearing required for a Walrasian general equilibrium.

In order to provide a micro foundation for a neo-Schumpeterian price theory, it is necessary to go further than writing a pricing rule with exogenously determined technology and gross profit margin. The theory also needs to include specification of the firm behaviour that generates these rules over the longer run and, in particular, incorporates the behaviour of entrepreneurial firms. In what follows, I provide this specification by building on post-Keynesian models of firm behaviour incorporating technological change, particularly the model of Sylos-Labini $(1962,1984) .{ }^{12}$

\footnotetext{
${ }^{12}$ For a discussion of the relationship between the pricing model of Sylos-Labini and other postKeynesian pricing models see Lee (1998), especially pp. 117-124.
} 
Sylos-Labini uses price leadership to explain how firms with different technologies and costs set a uniform price for their products. ${ }^{13}$ The price leader applies a pricing rule in the form of (2), while the other firms set identical prices. For the purpose of analysing the effects of innovation on prices, it is useful to express the implied price for each follower as follows:

$p_{i}=\theta_{i} \mu_{m}(x / y)_{i} w, \quad \theta_{i}=(x / y)_{m} /(x / y)_{i}$

where $p_{i}$ is an index of the price of the firm's products, $(x / y)_{i}$ is the firm's inverse productivity index and $\theta_{i}$ is a gross profit margin differential that compensates for the differences in productivity across firms.

In Sylos-Labini's analysis the price leader is the firm with the best-practice technology and, hence, the lowest costs, so $\theta_{i}$ is less than one. However, I start, as does Schumpeter, from a stationary state in which all such differences in technology would have been eliminated through creative destruction. All established firms in this mature market are using the best-practice technology and their prices are uniform even without price leadership. If an entrepreneurial firm introduces a new technology that has higher productivity and lower costs than the leading established firms, I assume it uses its cost advantage to earn entrepreneurial profit. Thus, applying the expression in (3) means that the entrepreneurial profit differential just offsets the innovator's productivity advantage, $\theta_{i}>1$.

Once a spurt of innovation is well underway, the further expansion of the innovative firms and their imitators, in part financed by their extra profits, generally requires undercutting the established price leader. The average price for all products

\footnotetext{
${ }^{13}$ The products may be undifferentiated, but for the purpose of the analysis below it is convenient to assume some differentiation so that price uniformity is a pricing strategy rather than an outcome imposed by a perfect market. An example is where firms with branded goods set equal prices for their products.
} 
at the industry level is then no longer equal to the price charged by the leader. ${ }^{14}$ Instead, the average price is given by a weighted sum,

$p=s_{m} p_{m}+s_{i} p_{i}, s_{m}+s_{i}=1$

where $s_{m}$ is the share of the price leader and its followers in the aggregate sales of firms in the industry, or economy, and $s_{i}$ is the corresponding share of entrepreneurial firms. Manipulating (4) yields,

$p=p_{m}-s_{i}\left(p_{m}-p_{i}\right)$

which shows that a rising share for innovative firms depresses the average industry price by an amount that rises with the degree to which the innovative firms undercut the price leader.

Cycles and trends in the price level can be analysed by substituting from (2) and (3) into (5) and reorganizing terms to separate influences with differing cyclical and secular patterns, yielding,

$p=\mu_{m}(x / y)_{m} w\left(1-s_{i}\left(1-\theta_{i}\left[(x / y)_{i} /(x / y)_{m}\right]\right)\right)$

For simplicity in exposition, innovation is treated as having a one-off impact on productivity of the innovator, which means the input-output ratios for both established and innovative firms are constant over the cycle. ${ }^{15}$ Also, in line with the standard approach of post-Keynesian pricing models, the gross profit margin of established firms, $\mu_{m}$, is treated as constant over the cycle. The remaining variables, $s_{i}, \theta_{i}$ and $w$, each has an endogenous pattern of movement over the cycle based on Schumpeter's theory.

Schumpeter argues that business cycles are unavoidable in capitalism because this is the mechanism by which innovators displace established firms. In the upswing

\footnotetext{
${ }^{14}$ As noted above, price differentials suggest there is at least minimal product differentiation.

15 This assumption can be relaxed to allow for internal or external economies of scale as production with the new technology is expanded. Relaxing this assumption would speed the process of domination by the innovators as, for example, in Steindl (1976 [1952]).
} 
of the cycle this involves competition for means of production, with the innovative firms using credit to secure inputs at the expense of the established firms. This competition pushes up the prices of primary inputs. ${ }^{16}$ With a rise in $w$, there is a proportional rise in the average price in (6). The rising share of innovators, $s_{i}$, does not immediately affect the average price as they set prices equal to the price leader. Importantly, the rise in input prices affects all industries that use any of the same inputs in their production processes, so a general rise in prices occurs that satisfies Schumpeter's concept of a rise in the price level. ${ }^{17}$

In the downswing of the primary cycle, the upward pressure on prices of primary inputs abates and the rate of change may then turn negative as credit is withdrawn from the system through the repayment of loans out of entrepreneurial profits. ${ }^{18}$ In addition, creative destruction contributes an impetus to a falling price level through its effects on the price system. Aggressive competition of innovative firms for market share through price reductions or quality improvements relative to the mature producers means that the price index for the industry directly subjected to innovation, $p$, falls both as the share of innovative firms, $s_{i}$, rises and as their extra gross margin, $\theta_{i}$, falls. Other industries that compete with the industry experiencing innovation for buyer expenditures will find their prices under downward pressure or

\footnotetext{
${ }^{16}$ Schumpeter (1939, p.480) in commenting on observed cyclical price movements acknowledges. 'that the producers' goods price composite, although it displays substantially the same rhythm as the consumers' good composite, shows greater amplitudes and generally also some precession.'

${ }^{17}$ In distinguishing between changes in the price level and the price system, Schumpeter (1939, p. 453) notes that, the price level, or monetary parameter, is not a mere statistical aggregate', so that determining the direction of the change in the price level is not simply a matter of taking a weighted average of changes across the price system. However, a rise in the input price vector, interpreted all elements either remaining unchanged or rising, would lead to the output price vector across all industries also rising, even if allowance were made for some products being used as intermediate products.

${ }^{18}$ As noted above in the discussion of the criticisms of Schumpeter's theory, whether or not the index of labour and raw materials prices falls below its original level depends on the type of institutional arrangements prevailing in the economy. The institutional influences operating on the vector of input prices is considered more fully below.
} 
their market shares falling, either of which adds to the downward forces on the aggregate price index for the economy. ${ }^{19}$

The primary cycle ends with innovative firms dominating so $s_{i}$ approaches one from below. Also, entrepreneurial profit disappears, so $\theta_{i}$ approaches $\mu_{i} / \mu_{m}$ from above, where $\mu_{i}$ is the gross profit margin for entrepreneurial firms once entrepreneurial profit is removed. $\mu_{i}$ is larger or smaller than $\mu_{m}$, depending on changes in market power and the allowance for obsolescence along with changes in indirect costs relative to direct costs. In the limit, the expression in (6) simplifies to, $p=\mu_{i}(x / y)_{i} w$

In (7), the input-output ratio and gross profit margin for the entrepreneurial firms replace the corresponding ratio for established firms in (2). ${ }^{20}$ In effect, the entrepreneurial firms replace established firms both in terms of production and in terms of pricing.

With entrepreneurial firms maturing as they become dominant, a new "normal" emerges and the primary wave of Schumpeter's cycle is ready to begin anew once a cluster of innovations emerges. However, this is delayed by the depression and recovery phases of the secondary wave in Schumpeter's business cycle schema. The decline in the price level and subsequent recovery that occur in these phases need to also be explained in the revised theory.

Primary production is assumed to be competitive both by Schumpeter and in the revised theory. Schumpeter attributes price-quantity cycles in coffee, hogs and

\footnotetext{
${ }^{19}$ As noted earlier, whether this constitutes a falling price level in Schumpeter's concept depends on the generality of the falling prices throughout the price system.

${ }^{20}$ Metcalfe (2007) presents a broadly similar analysis of dynamic competition among firms with heterogeneous costs drawing on Marshall's concept of the representative firm, except the representative firm is taken to be the average firm in terms of cost. Industry price is set equal to the unit cost of the representative firm. Firms with relatively high costs are then unable to cover their costs and exit the industry, which means that the representative firm is fitter and has lower cost and price eventually approaches best practice as suggested by the concept of creative destruction.
} 
shipbuilding to lagged supply responses in competitive markets. Rostow (1978) further argues that lagged supply response applies broadly to industrial materials and energy, due to long time lags required for discovery, planning and construction of new production capacity. As a result of lagged supply response, the primary cycle in raw material prices is mirrored, with a substantial lag, in the movement of production capacity for raw materials, which overshoots the demand growth in the manufacturing sector.

With production capacity overshooting demand in a competitive market, prices for raw materials fall below reproduction cost. In this way, the price level in (7) falls below "normal" levels, even when the gross margin, $\mu_{i}$, remains constant. A subsequent rise in the price of raw materials is expected as supply shrinks with a lag following the decline in prices in the downswing of the primary cycle. ${ }^{21}$ Without further disturbances, prices of raw materials may eventually move towards reproduction costs resulting in a new "normal" for the price system, although this depends on the stability of the oscillations in the price-quantity cycle for raw materials.

The secondary cycle in raw material prices is independent of any collapse in output or employment levels, although the latter may contribute to repressing wage growth that might otherwise offset the decline in raw material prices. ${ }^{22}$ Schumpeter doesn't explicitly recognize a secondary wave in prices of raw materials or producer goods more generally, but he does acknowledge the role of excesses in investment during the primary wave as contributing to overshooting at the end of the primary

\footnotetext{
${ }^{21}$ For a discussion of the behaviour of primary commodity prices over the Kondratieff cycles of the past few centuries see Bloch and Sapsford (2013).

${ }^{22}$ Financial crises are another possible influence on prices of primary inputs, but their impact is much more keenly felt on asset prices. Links between asset prices and the overall price level have not been clearly demonstrated and are beyond the scope of this study.
} 
cycle. He also acknowledges a role for expectations as contributing to the secondary wave, particularly expectations based on the extrapolation of recent trends.

Schumpeter's conclusion that the price level is subject to downward "result" trend over the full business cycle relies the impact of rising productivity. This impact is captured in the revised theory with the input-output ratio for entrepreneurial firms in (7) displacing the higher ratio for established firms in (2). However, the result trend is also impacted by changes in the input price index, $w$, and by the gross profit margin for entrepreneurial firms, $\mu_{i}$ displacing that for established firms, $\mu_{m}$.

As noted in the criticisms of Schumpeter's analysis in Section 3 above, both the gross profit margin and the price index of primary inputs, $w$, are subject to institutional influences. In modern production, the dominant component of the primary input index, $w$, is the wage rate for labour. Each country has its own specific institutional arrangements for wage setting, but the major economies that dominate world industrial production all have experienced sustained wage inflation since at least the middle of the $20^{\text {th }}$ Century. Further, wage growth has generally been explicitly or implicitly linked to preceding consumer price inflation, creating a wageprice spiral as well as a tendency for real wages to rise.

Raw materials prices are emphasized in the discussion of cyclical movements of primary input prices because competitive markets for raw materials lead to high sensitivity of raw material prices to supply and demand influences, at least as compared to the muted cyclical movements in wages under modern institutional arrangements. In terms of long-run trend, raw material prices have tended to fall relative to both wages and prices of finished goods. This reflects both more competitive institutional arrangements and the impact of productivity improvements in agricultural and mining production. However, the relative deflation in raw material 
prices plays only a small role in the trend in the overall price level, as the share of raw materials in the value of inputs to production is much smaller than that of labour.

As shown in (6) and (7), the average industry price rises proportionally with the gross profit margin of the price leader. While the same factors influence gross margins for the innovators as influenced those of their predecessors, the rising share of overheads in total costs over time and the increasing recognition of the threat of obsolescence due to creative destruction are forces that suggest upward step changes in the margin, with $\mu_{i}>\mu_{m}$.

Rising gross profit margins for finished goods prices have been generally observed in the modern era. Bloch and Sapsford (2000) find trend growth in the average gross profit margin for manufacturing in the US and UK of somewhat more than .0035 per year over the period from 1948 to1993. While small on an annual basis, that rate applied for a century adds more than .5 to the multiple by which the average price of finished goods exceeds the average direct cost of production.

Schumpeter's treatment of money and credit is criticized in Section 3 above for failing to properly account for the evolution of institutions affecting the supply of money and credit. During the third quarter of the $20^{\text {th }}$ Century, money and credit expanded to accommodate the inflationary wage-price spiral in most industrialized countries. Subsequently, inflation targeting by central banks became fashionable and rates of growth in both wages and finished goods prices slowed while remaining generally positive. It is arguable that the accommodation phase coincided with the upswing phase of a Kondratieff cycle and that the inflation-targeting phase coincided with the downswing, reinforcing the pro-cyclical movement in the price level. However, the net inflation over the full period clearly contradicts Schumpeter's prediction of a downward trend in the price level and demonstrates the importance of 
incorporating the evolution of the institutional arrangements for money and credit into the analysis of inflation in the modern economy along with an analysis of the evolution of institutions directly affecting wage and price determination.

Overall, the sustained inflationary experience of capitalist economies over the past century is attributable to institutional influences overwhelming the productivity increases flowing from economic development. Direct influences have been labour market institutions that have led to sustained wage inflation and changes in price setting by dominant firms that have led to rises in gross profit margins in manufacturing, while an accommodating monetary policy is noted as an indirect influence. By failing to consider the impact of these influences, Schumpeter did not foresee the changing result trend for prices.

\section{Conclusions}

Schumpeter provides a theory of economic development that contains within it a theory of both the price level and the price system under conditions of discontinuous change associated with innovation. Schumpeter takes the Walrasian theory of general equilibrium for a stationary economy as the starting and end point for the process of economic development, but he then clearly distinguishes the price theory that applies during the process of development. In particular, instead of prices that gravitate towards equilibrium whenever the economic system is shocked from outside, Schumpeter argues for an endogenous process of development that permanently disturbs the price system from within as well as generating a long cycle in the price level. Thus, Schumpeter provides a theory of prices in motion rather than a theory of equilibrium prices. 
Schumpeter's theory has been justly criticized on both theoretical and empirical grounds. In particular, an economy that has undergone development is fundamentally different than an economy in a stationary state, even if the development process is temporarily subdued or suspended. The expectation of change remains and affects investment decisions. Thus, it is argued that the position of subdued innovation between the digestion of one wave of development and the beginning of the next can't logically correspond to the Walrasian equilibrium associated with a continually repeating circular flow. Further, it is argued that Schumpeter's theory is a theory of macroevolution, without the supporting analysis of the micro-level behaviour of firms or of the meso-level process of dynamic competition within and across industries.

These criticisms are addressed by sketching a neo-Schumpeterian theory of prices in motion that differs from Schumpeter's analysis in three main dimensions. First, the revised theory draws on post-Keynesian models of price determination at the firm level. Second, this micro-level analysis is combined with a meso-level analysis of the evolution of price leadership between established and entrepreneurial firms, which provides cyclical dynamics to the movement of the price system and the price level. Finally, movements in prices of primary inputs (labour and raw materials) are incorporated at the macro level, noting the impact of institutional arrangements on the dynamics of wage rates and primary commodity prices.

In the revised theory, the theoretical normal for prices is based on price leadership by dominant firms rather than the competitive equilibrium of the circular flow for a stationary economy. A key difference is that prices are increased both by a premium for prospective obsolescence of inputs committed to the current technology and by the imperfection of competition. The obsolescence premium is related to the 
perceived threat of loss in value of committed inputs that could be employed more productively with a future technology once it is introduced, while imperfect competition is a necessary concomitant of an economy driven by innovation as is clearly acknowledged by Schumpeter. Thus, the theoretical normal for price in the revised system is higher than in the competitive equilibrium of the stationary state, with the degree of price elevation increasing with the dependence on the use of inputs committed to the current technology and on the degree of imperfect competition, which means that the process of development comes at a cost.

The revised theory generates a price cycle with Schumpeterian characteristics following a burst of innovations. Further, the innovations impart a downward tendency to the price system as suggested by Schumpeter due to productivity improvement over the course of the price cycle. However, this downward trend can be offset by the evolution of gross profit margins and prices of primary inputs, especially labour, which explains the systemic inflation in modern industrialized countries observed over the course of the $20^{\text {th }}$ Century. This contradiction of Schumpeter's prediction is attributed to his failure to account for institutional evolution. Further institutional evolution will no doubt occur with future price cycles and influence the resulting price trends.

Schumpeter's great insight is that the capitalist system is continually subjected to discontinuous change due to disruptive innovation. While his price theory is flawed, at least it is aimed at the correct problem of analysing pricing in a capitalist system undergoing economic development. The revised theory sketched above accounts for the evolution of institutions and pricing practices in the economy, thereby providing a way forward to a neo-Schumpeterian theory of prices in motion 
that is appropriate for the analysis of modern capitalist economies with their endogenous process of economic development. 


\section{References}

Andersen, Esben Sloth (2012), 'Schumpeter's Core Works Revisited - Resolved Problems and Remaining Challenges', Journal of Evolutionary Economics, 22: 627-648.

Bloch, Harry and Sapsford, David (2000), 'Whither the Terms of Trade? An Elaboration of the Prebisch-Singer Hypothesis', Cambridge Journal of Economics, 24: 461-481.

Bloch, Harry and Sapsford, David (2013), 'Innovation, Real Primary Commodity Prices and Business Cycles', in Esben Andersen and Andreas Pyka, editors, Long Term Economic Development - Demand, Finance, Organization, Policy and Innovation in a Schumpeterian Perspective, Berlin, Springer: 175-189.

Dopfer, Kurt, Foster, John and Potts, Jason (2004), 'Micro-Meso-Macro', Journal of Evolutionary Economics, 14: 263-280.

Fischer, David Hackett (1996), The Great Wave: Price Revolutions and the Rhythm of History, Oxford, Oxford University Press.

Freeman, Christopher (1990), 'Schumpeter's Business Cycles Revisited' in A Heertje and M Perlman, Evolving Technology and Market Structure, Ann Arbor, University of Michigan Press, 17-38.

Freeman, Christopher and Louçã, Francisco (2001), As Time Goes By, Oxford, Oxford University Press.

Kuznets, Simon (1940), 'Schumpeter's Business Cycles', American Economic Review, 30: 257-71.

Lee, Frederic S. (1998), Post Keynesian Pricing Theory, Cambridge, Cambridge University Press. 
Lipsey, Richard G., Carlaw, Kenneth I. and Bekar, Clifford T. (2005), Economic Transformations, Oxford, Oxford University Press.

Mensch, Gerhard (1979), Stalemate in Technology, Cambridge, MA, Ballinger.

Metcalfe, J. Stanley (2007), 'Alfred Marshall's Mecca: Reconciling the Theories of Value and Development', Economic Record, 83: S1-22.

Oakley, Allen (1990), Schumpeter's Theory of Capitalist Motion: A Critical Exposition and Reassessment, Aldershot, Hants, Edward Elgar Publishing.

Prebisch, R (1950), “The economic development of Latin America and its principal problems", United Nations ECLA; also published in Economic Bulletin for Latin America (1962), 7, 1-22.

Rostow, Walter W. (1978), The World Economy: History and Prospect, Austin, TX, University of Texas Press.

Rowthorn, Robert E (1977), “Conflict, inflation and money”, Cambridge Journal of Economics, 1, 215-239.

Sarantis, Nicholas (1991), "Conflict and inflation in industrial countries", International Review of Applied Economics, 5, 155-169.

Schumpeter, Joseph A. (1961 [1934]), The Theory of Economic Development (translation of second German edition by Redvers Opie), London, Oxford University Press.

Schumpeter, Joseph A. (1939), Business Cycles, Volumes 1 and 2, New York, McGraw-Hill.

Schumpeter, Joseph A. (1950 [1942]), Capitalism, Socialism and Democracy, third edition, New York, Harper and Row. 
Singer, H W (1950), "The distribution of gains between investing and borrowing countries", American Economic Review, Papers and Proceedings, 40, 473485.

Steedman, Ian (1992), "Questions for Kaleckians", Review of Political Economy, 4, $125-151$.

Steindl, Josef (1976 [1952]), Maturity and Stagnation in American Capitalism, New York, Monthly Review Press.

Sylos-Labini, Paolo (1962), Oligopoly and Technical Progress, Cambridge, MA, Harvard University Press.

Sylos-Labini, Paolo (1984), The Forces of Economic Growth and Decline, Cambridge, MA, MIT Press.

Tylecote, Adnrew (1992), The Long Wave in the World Economy, London, Routledge. Warburton, Clark (1953), 'Money and Business Fluctuations in the Schumpeterian System', Journal of Political Economy, 61: 509-522. 